\title{
Seniors, vermijd wreed optimisme en gebruik je positie
}

\author{
Yvonne La Grouw*
}

\begin{abstract}
Een discoursanalyse van taal van senior onderzoekers over publicatiedruk onder jonge wetenschappers laat zien dat de goede bedoelingen van seniors een bepaalde wreedheid in zich hebben. In een lezing op een summerschool werden promovendi aangespoord zich niets aan te trekken van publicatiedruk vanuit 'het systeem', terwijl seniors in comfortabele professoraanstellingen de universiteit op bijna fatalistische wijze abstraheerden tot een rigide publicatiefabriek waar zij zelf genoodzaakt zijn aan mee te werken. In plaats van jonge academici een rooskleurig, maar uiterst onzeker, toekomstperspectief voor te houden, worden zij beter geholpen wanneer senior onderzoekers (vertellen over hoe zij) zich hard maken voor waardering van kwaliteit.
\end{abstract}

Afgelopen zomer was ik in Boedapest op een summerschool om te leren over Critical Discourse Analysis. Als je eenmaal geleerd hebt om naar politieke dimensies van taalgebruik te kijken, is het lastig om buiten het leslokaal of je onderzoek dat niet meer te doen. Zo nam ik op de summerschool deel aan een lezing voor $\mathrm{PhD}$-studenten over onder andere het 'publish or perish'-debat met drie senior wetenschappers binnen de politieke wetenschappen. Gedurende deze lezing groeide mijn verbazing over de dubbelheid van hetgeen er gezegd werd. Naderhand sprak ik een mede PhD-student die vol nieuwe moed de lezing had verlaten, terwijl ik ondanks de goede bedoelingen van de sprekers - gevoelens van frustratie met moeite kon onderdrukken. Wat was er gezegd? Ik neem je graag mee terug naar de lezing, en zal mijn verbazing uitleggen door middel van een analyse met mijn recentelijk aangeleerde Critical Discourse Analysis-bril.

\section{'Wij' gingen altijd voor kwaliteit boven kwantiteit}

Het belangrijkste punt dat de drie senior wetenschappers in de lezing wilden maken is dat promovendi zich niet gek moeten laten maken door publicatiedruk, omdat kwaliteit belangrijker is dan kwantiteit. Bij het maken van dit argument presenteerden de seniors sociale verhoudingen binnen de wetenschap door middel van de discursieve strategie genaamd 'nominatie' (Reisigl \& Wodak, 2001). Nominatie gaat over het construeren van in-groups en out-groups: over het benoemen van 'ons' (in-group) en 'hen' (out-group). De seniors spraken over 'wij' wanneer zij het hadden over wetenschappers die oog hebben voor kwaliteit.

* Yvonne La Grouw is PhD-student sociologie aan de Vrije Universiteit Amsterdam. 
Wetenschappers en bestuurders die gericht zijn op kwantiteit ('publicatieaantallen, cijfers en geld'), werden gepresenteerd als de 'andersdenkenden'. Door deze 'kwantiteit'-gerichte groep als 'ander' neer te zetten, verduidelijkten zij hun eigen kwaliteitgerichte positie.

Deze kwaliteit-liefhebbende 'wij' werd in een heldenrol geplaatst. Zo vertelde een professor hoe hij na jaren goed onderzoek doen in zijn zesde PhD-jaar zijn eerste artikel publiceerde. Het zou voor hem niet eens mogelijk zijn om in zijn derde jaar te publiceren, 'zoals men tegenwoordig van $\mathrm{PhD}$-studenten verlangt', vertelde hij lachend. De professor maakt hier gebruik van de differentiation-techniek (Van Leeuwen, 1996), waarin hij zichzelf als $\mathrm{PhD}$-student positief onderscheidt van $\mathrm{PhD}$-studenten die snel publiceren. Een andere senior benadrukte in de lezing tweemaal dat hij veel waarde hecht aan 'big ideas and big papers' en raadde $\mathrm{PhD}$ studenten aan om zoveel tijd te nemen voor een artikel als mogelijk. In dit discours zijn twee topoi te herkennen, dat wil zeggen algemene argumentatiestructuren of referentiepunten die gebruikt worden om een argument te maken (Reisigl \& Wodak, 2001). Door het verbinden van de topoi 'kwaliteit' en 'tijd nemen' presenteren de seniors zichzelf als voorvechters van het lang werken aan een goede publicatie.

\section{Systeemslachtoffer met goede bedoelingen}

Naast een heldenrol werd ook een slachtofferrol aangenomen in het seniordiscours, zoals blijkt uit onderstaande observatie:

Een $\mathrm{PhD}$-student in de zaal stelt de vraag waar de seniors zelf op letten bij het aanstellen van jonge wetenschappers na hun $\mathrm{PhD}$. Het antwoord is volgens alle drie seniors duidelijk: je moet toch tenminste één goede publicatie hebben. Het aanstellen van een junior zonder publicaties 'zou een groot probleem zijn', aldus een van de seniors. Hij somt de redenen op: 'Ik zou graag puur willen selecteren op kwaliteit, maar stel dat ik iemand wil aannemen zonder publicaties. Dan zou ik allereerst de andere leden van de sollicitatiecommissie moeten overtuigen; en stel dat dat me lukt - dan moet ik de leden van mijn onderzoeksgroep overtuigen; en stel dat dat me lukt - dan moet ik het afdelingshoofd overtuigen; en zelfs als dát lukt - moet ik naar zijn baas voor toestemming, en eindig ik bij de bestuurders en beleidsmensen van de universiteit.' Zuchtend concludeert de senior: 'Zij, daarboven, zijn alleen geïnteresseerd in publicatieaantallen, cijfers en geld.'

In het taalgebruik van de professor zijn verschillende discursieve technieken te herkennen die bijdragen aan een proces van othering: het identificeren van anderen als anders dan jijzelf of van de massa, waarmee een machtsrelatie tussen ' $\mathrm{ik}$ ' en de 'ander' versterkt of opnieuw geconstrueerd wordt (Johnson e.a., 2004). Het othering-proces in bovenstaande observatie creëert een beeld van machteloosheid en een slachtofferpositie van de professor. Zo wordt de jonge wetenschapper zon- 
der publicaties geïmpersonaliseerd door hem of haar te abstraheren tot 'een probleem' binnen het universiteitssysteem (Van Leeuwen, 1996). Hiermee brengt hij de identiteit en capaciteiten van de jonge wetenschapper naar de achtergrond en komt de nadruk te liggen op hetgeen dat 'mis' is: te weinig publicaties.

Door het beschrijven van een onderhandelingsproces in een veelheid aan hiërarchische lagen, en de uitspraak 'zelfs als dát lukt', benadrukt de professor de ervaren complexiteit van de universitaire hiërarchie. Het repetitieve grammaticale patroon werkt als een intensifiëring (Reisigl \& Wodak, 2001) van deze complexiteit én van de predicatie van personen met 'beslisrecht' in de universiteit. Predicatie gaat over het toeschrijven van positieve of negatieve eigenschappen aan actoren (Reisigl \& Wodak, 2001). De professor beschrijft personen met beslisrecht als actoren die per definitie een ander standpunt hebben dan hij (gericht zijn op kwantiteit), en dus overtuigd moeten worden. Door herhaling wordt het idee versterkt dat hij bij al deze actoren tegen dezelfde weerstand aanloopt.

Vervolgens wordt het bediscussiëren van het aannemen van een junior wetenschapper zonder publicaties neergezet als een kansloze praktijk door nominatie van de universiteitsbestuurders en beleidsmedewerkers als 'zij, daarboven'. De professor gebruikt stereotypering als predicatietechniek, aangezien 'daarboven' een metaforische verwijzing is naar mensen met macht die ver van 'ons' afstaan, die in 'de ivoren toren' zitten. Hij geeft als argumentatie (Reisigl \& Wodak, 2001) voor de gestelde predicatie dat bestuurders en beleidsmedewerkers alleen geïnteresseerd zijn in publicatieaantallen, cijfers en geld. Door middel van zuchten wordt zijn boodschap van machteloosheid in een hiërarchisch systeem geïntensifieerd. Dit discours wekt een fatalistisch gevoel op: tegen de gevestigde orde ingaan is zinloos.

Door zichzelf te presenteren als slachtoffer met goede bedoelingen in een rigide machtssysteem plaatst de senior zijn rol in de universiteit naar de achtergrond, hij maakt zichzelf een onbelangrijk personage in de discussie over publicatiedruk en aanstellingsbeleid. Deze strategie wordt ook wel backgrounding genoemd (Van Leeuwen, 1996). Tegelijkertijd presenteert hij anderen als de beslismakers: hij foreground (Van Leeuwen, 1996) de sollicitatiecommissie, het afdelingshoofd en eenieder in de lagen bureaucratie van de universiteit. Door deze back- en foregrounding maakt de professor zichzelf een passieve actor (Van Leeuwen, 1996) in het zijn verhaal: hij 'ondergaat' de macht van de bureaucratie. De andere actoren worden gepresenteerd als actieve actoren (Van Leeuwen, 1996): zij houden de 'minstens één publicatie'-norm staande, ze werken hem tegen. Door middel van deze technieken slaagt de professor, wederom, in differentiation: hij presenteert zichzelf als onderdeel van het universiteitssysteem, maar als de positieve uitzondering, omdat hij - in tegenstelling tot zijn collega's - voorstander is van kwaliteit boven kwantiteit.

De argumentatie van deze professor kan beschouwd worden als calculated ambivalence.(Wodak \& Engel, 2013). Calculated ambivalence is een manier om twee ideologisch tegenstrijdige boodschappen in één uitdrukking over te brengen. Zo kan 
een verschillend publiek, met verschillende standpunten en belangen, aangesproken worden. Enerzijds geeft de professor aan dat publicaties niet uit moeten maken voor jonge academici, anderzijds geeft hij aan dat hij het niet zinvol acht daarvoor te strijden als hij zelf op zoek gaat naar jong wetenschappelijk personeel: ik wil er wel wat aan doen, maar ik ga er niets aan doen.

Het geven van deze dubbele boodschap en het positioneren van zichzelf als slachtoffer in een hiërarchisch systeem kan begrepen worden als een blame avoidance-strategie: het vermijden van het krijgen van schuld (Hansson, 2015). Door de backgrounding- en passivisation-strategieën die ik hierboven besprak, lijkt het alsof de professor geen positie bekleed met enige handelingsruimte wat betreft het aanstellingsbeleid van jonge onderzoekers. Door zijn repetitieve argumentatiestijl benadrukt hij wat hij niet kan betekenen voor jonge onderzoekers zonder publicaties. De predicatie van de bestuurders en beleidsmakers met wie niet te praten valt, vormt de uiteindelijke dooddoener in de beschouwing van de mogelijkheden van de professor tot het uitoefenen van invloed.

\section{Wreed optimistische 'senior talk'}

Gedurende de lezing bekroop mij een gevoel van wat Lauren Berlant (2008) beschrijft als 'wreed optimisme'. Wreed optimisme gaat over het hechten aan condities van een mogelijkheid, welke of onmogelijk is, of pure fantasie, of mogelijk is maar ten koste gaat van het welzijn van het individu. Het bieden van een wreed optimistisch toekomstperspectief vindt meestal plaats vanuit de gedachte dat het de last van een persoon kan verlichten, of uit angst dat deze persoon zonder dit perspectief al zijn hoop verliest. Dit fenomeen lijkt zich concreet voor te doen in de volgende observatie van 'senior talk' in de lezing:

Een PhD-student vertelt dat zijn PhD-contract bijna afloopt en zijn universiteit sterk aanstuurt op een publicatie. Zijn werkgever is helder: hij kan een vervolgcontract vergeten wanneer hij geen publicaties heeft aan het eind van de rit. Een professor reageert: 'Ik hoop dat je deze hobbels overwint, want daarna lonkt een prachtig perspectief: een vaste aanstelling.' Ze vertelt glunderend hoe zij sinds haar vaste aanstelling een grenzeloze vrijheid ervaart in haar werk. Ze heeft zelfs een wetenschapsfilosofische paradigmashift gemaakt, en niemand kon haar hierin tegenhouden. De professor geeft aan dat ze hoopt dat dit toekomstbeeld de PhD-student 'hoop geeft om vol te houden in deze lastige fase'.

In dit voorbeeld schetst de professor de PhD-student een object van verlangen, namelijk een vaste aanstelling in de wetenschap met grenzeloze academische vrijheid. Het object van verlangen is bovendien gerelateerd aan fundamentele voorwaarden aan het welzijn van de PhD-student in kwestie. Een vaste aanstelling biedt namelijk inkomensgarantie, waarmee hij zijn huur kan betalen, eten kan kopen, gezondheidszorg kan betalen, et cetera. Het devies van de seniors wat 
betreft publicatiedruk is geduld blijven houden en blijven werken aan die ene (hopelijk) toppublicatie. Het opvolgen van dit advies kan, echter, ten koste gaan van het welzijn van de PhD-student. Lang de tijd nemen en je pijlen richten op één grote publicatie gaat ten koste van je contract, want dat verloopt toch echt na drie of vier jaar. Zonder publicatie hebben jonge onderzoekers weinig zicht op een vervolgplek, zoals de seniors erkenden. Bovendien is het algemeen bekend dat er te weinig posities in de wetenschap zijn voor net gepromoveerden, laat staan een vaste aanstelling. Het negeren of backgrounden van deze realiteit draagt bij aan een onterecht optimisme.

Het enerzijds aansporen van promovendi om zich niets aan te trekken van publicatiedruk en hen doen verlangen naar gouden bergen na de $\mathrm{PhD}$, en het anderzijds meewerken aan het in stand houden van een systeem dat academische waarde verbindt aan publicatieaantallen, is niet constructief. Toch twijfel ik niet aan de goede intenties van deze senior wetenschappers om promovendi in de lezing verder te helpen met hun carrière. Als medewetenschapper begrijp ik de kafkaëske gevoelens van de seniors die gepaard gaan met het werken in de academie natuurlijk wel. Het kan daarbij logisch en comfortabel zijn om jezelf te backgrounden of als passief slachtoffer van het systeem te beschouwen. Echter, om jonge onderzoekers onder publicatiedruk écht te helpen, moeten ervaren wetenschappers zich actief verzetten tegen systeempraktijken waar zij het niet mee eens zijn, in plaats van in de slachtofferrol te kruipen en geen verantwoordelijkheid te nemen voor het proces waar zij zelf deel van uitmaken. Als mensen in professorposities al geen inspraak meer (zouden) hebben in het aanstellingsbeleid van jonge onderzoekers, wordt de aansporing om optimistisch te blijven over onze toekomst als wetenschappers des te wreder.

Dit betoog gaat niet over het afschaffen van een 'minstens één publicatie'-regel. Het gaat over het veranderen van de houding van senior wetenschappers in het publicatiedrukdebat, van passiviteit en wreed optimisme naar actie en constructieve discussies wat betreft de waardering van kwaliteit en realistische carrièrepaden voor jonge onderzoekers. Hoe bepalen we hoe we kwaliteit waarderen? Wie heeft daar zeggenschap over en wie zou dat moeten hebben? Wat gebeurt er als we de discussie met 'andersdenkenden' aangaan? Wat kun je vanuit jouw positie wél betekenen? Er zijn bovendien een hoop belangrijkere zaken om over te praten wat betreft kwaliteitswaardering dan het romantiseren van het verleden en de toekomst. Zo speelt bijvoorbeeld gender bias nog steeds een grote rol in carrièrepaden van onderzoekers (zie bijvoorbeeld Van der Lee \& Ellemers, 2015), een onderwerp dat weinig serieuze aandacht krijgt - misschien wel omdat dit niet past binnen het 'kwaliteit boven alles'-discours.

Uiteraard zijn mijn bevindingen geen generalisatie naar het discours van alle senior onderzoekers. Desalniettemin nodig ik eenieder uit te reflecteren op zijn houding in het publicatiedrukdebat. In hoeverre zijn daar elementen van heldenverhalen over het verleden, slachtofferschap in het heden en wreed optimisme over de toekomst in terug te vinden? Laten we voortaan praten over (het creëren 
van) realistische mogelijkheden in het heden, en wat jij daar vanuit jouw positie in kunt - of zou moeten kunnen - betekenen.

\section{Literatuur}

Berlant, L. (2008). Cruel Optimism: On Marx, Loss and the Senses. New Formations: A Journal of Culture/Theory/Politics, 63: 33-51. https://doi.org/10.3102/ 00346543067001043.

Hansson, S. (2015). Discursive strategies of blame avoidance in government: A framework for analysis. Discourse and Society, 26 (3): 297-322. https://doi.org/10.1177/ 0957926514564736.

Johnson, J.L., Bottorff, J.L., Annette, J., Grewal, S., Hilton, B.A., \& Clarke, H. (2004). Othering and being othered in the context of health care services. Health Communication, 16 (2): 255-271. https://doi.org/10.1207/S15327027HC1602.

Lee, R. van der, \& Ellemers, N. (2015). Gender contributes to personal research funding success in The Netherlands. Proceedings of the National Academy of Sciences, 112 (40): 12349-12353. https://doi.org/10.1073/pnas.1510159112 .

Leeuwen, T. van (1996). The Representation of Social Actors. In: C.-R. Caldas Coulthards \& M. Coulthard (red.), Texts and Practices - Readings in CDA. Londen: Routledge.

Reisigl, M., \& Wodak, R. (2001). Discourse and Discrimination. Londen: Routledge.

Wodak, R., \& Engel, J. (2013). 'Calculated ambivalence' and Holocaust denial in Austria. In: R. Wodak \& J.E. Richardson (red.), Analysing Fascist Discourse: European Fascism in Talk and Text. Routledge, 83-106. https://doi.org/10.4324/9780203071847. 